\title{
The Effects of Forests on Precipitation
}

\author{
By DOUGLAS L. GOLDING
}

Canadion Forestry Service

Edmonton, Alberta

ODC 116.1

"... forests have very little effect on the total amount of precipitation falling on extensive regions or even on local areas."

\begin{abstract}
Debate has continued for many years as to the influence of the forest on the amount of precipitation falling in the vicinity of the forest itself as well as over wide regions. Evidence for such an influence is reviewed with reference to measurement of rainfall within the forest and moistening of the atmosphere by forest transpiration. Much of this evidence is circumstantial, some of which is based only on casual observation. Meteorological factors such as orographic effect, condensation and freezing nuclei, and vapor content of the atmosphere are discussed. This evidence, while based on analyses of the physical system, is not conclusive or completely satisfying either. The conclusion reached is that the maximum effect that may reasonably be attributed to the forest is a five per cent increase in precipitation, and this only in particular circumstances.
\end{abstract}

\section{L'influence de la forêt sur la précipitation}

\section{Resume}

Le débat est ouvert depuis plusieurs années au sujet de l'action du milieu forestier sur la quantité d'eau de précipitation qui tombe dans les environs immédiats autant qu'éloignés de la forêt. La démonstration de l'influence de la forêt est remise en question en faisant appel à ses résultats de mesure de précipitation et d'évapo-transpiration. Une

${ }^{1}$ From a thesis submitted by the author to the University of British Columbia as part of his Ph.D. program.

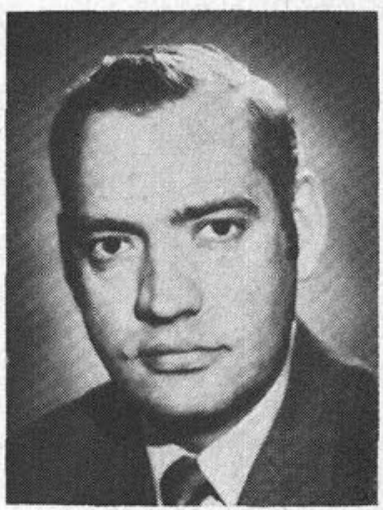

grande part d'évidence a été établie de façon indirecte et à partir d'observations fortuites. Les facteurs météorologiques comme l'action orographiques, les noyaux de condensation et de congélation, de même que le contenu en vapeur d'eau de l'atmosphère sont soumis à la discussion. La preuve, basée sur études du système physique, n'est pas concluante ni satisfaisante. L'effet maximum qui peut être de façon raisonnable attribué à la forêt ne représente qu'une augmentation de $5 \%$ de la précipitation et là encore dans des conditions particulières.

\section{Introduction}

Trees, whether singly, in small groups, or in extensive stands, influence the amount of precipitation falling on adjacent areas of the earth's surface. They do this by (1) influencing the flow of wind in the vicinity, as would any physical obstruction, and hence the depositional pattern of rain and to an even greater degree snow, and (2) interception. Forests influence the water regime of an area, as would any vegetative cover, by their consumptive use of water (i.e., transpiration) and by their effect on the energy balance of the region and hence on evaporation.

However, the effect of forests on the total amount of precipitation falling on or near the region in which the forests are located, or for that matter even distant regions, has long been debated. It is to this question that this paper is directed. 


\section{Review}

Evidence based on varying degrees of objectivity has been cited by observers to support their views of the forest influence on precipitation. Such views ranged from the opinion that precipitation increased with the cutting of forests, to the more common opinion that forests induce precipitation.

In 1864, the geographer G. P. Marsh summarized European and American evidence of the influence of forests on the hydrologic cycle and concluded that forest removal "has lessened the quantity [of precipation] which annually falls within particular limits" (Marsh 1965, p. 158). Later, Harrington (1902) reviewed the literature and concluded that the wealth of evidence indicating greater precipitation within forests, does "not prove, with entire conviction, that forests increase rainfall" (p. 111). Others, however, clung to the belief that forests induced precipitation. Gifford Pinchot (1909) stated that forests increased precipitation by 10 per cent, and Zon (1927) thought that forests increase precipipitation not just locally, but over extensive regions. Supporting evidence was of three kinds: (1) casual observation, (2) comparison of rainfall measurements within and outside forests, and (3) the opinion that forest transpiration provides moisture for further precipitation.

\section{Measurement of Rainfall Within the Forest}

Many measurements have shown greater rainfall catch in forest openings than in the open. Hughes (1949) reviewed many of these studies and pointed out the fundamental objection - no two areas are the same in all respects except for the presence or absence of forest. The main problem in rainfall measurement is gauge exposure. In the forest the gauge is protected to a varying extent from the wind whose velocity is usually only 20-40 per cent of that in the open (Kittredge 1948). Turbulent eddies set up by the gauge itself tend to decrease gauge catch relative to true precipitation. As wind speed increases turbulence increases and catch decreases. Storage gauges often have shields that divert overflow to minimize updrafts and turbulent eddies over the gauge orifice (Fig. 1). Another factor is that gauges in the forest are usually placed in small openings to avoid interception losses caused by intervening canopies. This adds a further confounding factor; turbulence caused by the hole in the canopy might decrease catch as is usual, or increase catch because of a downward component of the over-riding wind.

To avoid these problems it has often been suggested that precipitation gauges be placed above the canopy. Problems exist in gauging above the canopy, also, in that the wind above the canopy becomes very turbulent because of roughness and swaying tops (Geiger 1965). Also, wind velocity increases only gradually with height above canopy, and the height at which it attains open velocity increases with wind speed (Kittredge 1948). This means that a gauge above the canopy is far from being similarly situated to one on the ground in the

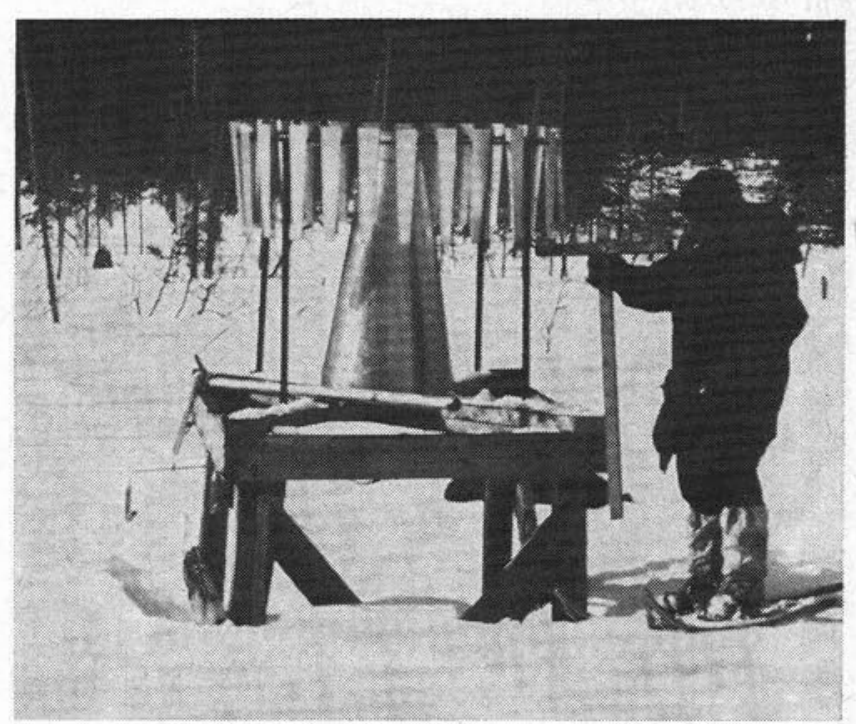

Fig. 1. Storage precipitation gauge with Alter shield. The freeswinging slats of the shield divert airflow to minimize turbulence over the gauge orifice.

open. Law (1958) described in detail the problems associated with gauging precipitation in the forest environment. Difficulties are greatly magnified in steep terrain as shown by Storr's (1967) study of precipitation variations on Marmot Creek experimental watershed (Fig. 2).

\section{Atmospheric Moistening by Forest Transpiration}

Dokuchaev (1892) and Kasatkin (1927) in Russia, and Zon (1935) in the United States, among others, held that a forested region would provide sufficient moistening of the atmosphere by transpiration to significantly increase precipitation. Dokuchaev promoted afforestation of the Russian steppes to prevent drought. Kasatkin reasoned that because precipitation on the arctic coast of Russia is low but increases proceeding inland toward the south, the northern forests provide moisture for rainfall in southern Russia. Zon supported the proposal for a shelterbelt 100 miles wide by 1200 miles long of forested strips stretching from North Dakota to Texas. He cited the advantages of such a belt of trees as reduction of wind velocity and hence evapotranspiration and soil blowing but stated that "whether shelterbelt planting, if carried out on a sufficiently large scale, will ultimately affect the climate over a wide territory is at present of purely academic interest" (Zon 1935, p. 393). By 1945 , Zon had conceded that forests do not increase precipitation significantly (Zon 1945).

Various tests and data analyses have been carried out by sceptics of the role in precipitation attributed to forests, but generally these have been inconclusive. Warren (1945), to determine the effect of evaporation on precipitation, analysed rainfall records for a site downwind of the Salton Sea, a 440-square mile area flooded in 1906. Mean annual rainfall for the next 12 years was 18 per cent greater than for the preceding 28 years. However, two other sites, beyond the effect of the sea, registered larger increases. Bernard (1945) calculated evaporation-rainfall ratios for four vegetation 
zones in the Congo River basin. He reasoned that if vegetation has an appreciable influence on precipitation, then the ratio of evaporation to precipitation should be greatest in the area with the highest evaporation. However, the highest ratio was in the type with the lowest evaporation, indicating by Bernard's reasoning that evapotranspiration from forests does not increase precipitation. Penman (1963), not satisfied with this reasoning, reached the same conclusion by showing that the three types that varied in degree of forest cover had about the same annual evaporation but a wide variation in rainfall.

Horton (1943) had observed that the amount of chlorine in runoff from the land decreases rapidly going inland from the coast. He assumed that the chlorine had entered the air over the ocean, acted as nuclei for condensation of water vapor, and had fallen to earth as precipitation. He concluded that since inland precipitation did not contain much chlorine, evaporation from the land surface was the source of such precipitation. Benton et al. (1950) pointed out however, that all the chlorine in coastal precipitation was not from condensation nuclei but was picked up by rain drops as they fall through air containing chlorine. In other words, the lack of chlorine in inland precipitation was not evidence of a land source for the precipitation but only a lack of chlorine in the air.

At this point in the debate, meteorological arguments were put forth. Holzman (1937) stated that dry periods are not caused by insufficient moisture in the atmosphere, but by lack of the physical forces needed to condense water vapor and cause it to precipitate. Sutcliffe (1956) concluded that the atmosphere generally contained a supply of moisture sufficient for about ten days of average rainfall. A water balance of the Mississippi River basin indicated that of the water vapor for precipitation, only eight to nine per cent originated in the basin itself (Benton et al. 1950). The authors denied the possibility of local land management even slightly affecting amount of precipitation. In a Russian study, the annual amount of moisture passing over a small watershed was estimated as 10 times the annual precipitation and 13 times annual evapotranspiration (Kashin and Pogosyan 1950; cited by Molchanov 1960). It was concluded that "evaporation does not play a very considerable part in the moistening of the atmosphere within continental areas" (Molchanov 1960, p. 4).

Rakhmanov (1962), dealing with European U.S.S.R., employed an interesting method for showing that water added to the air by forests is not sig-

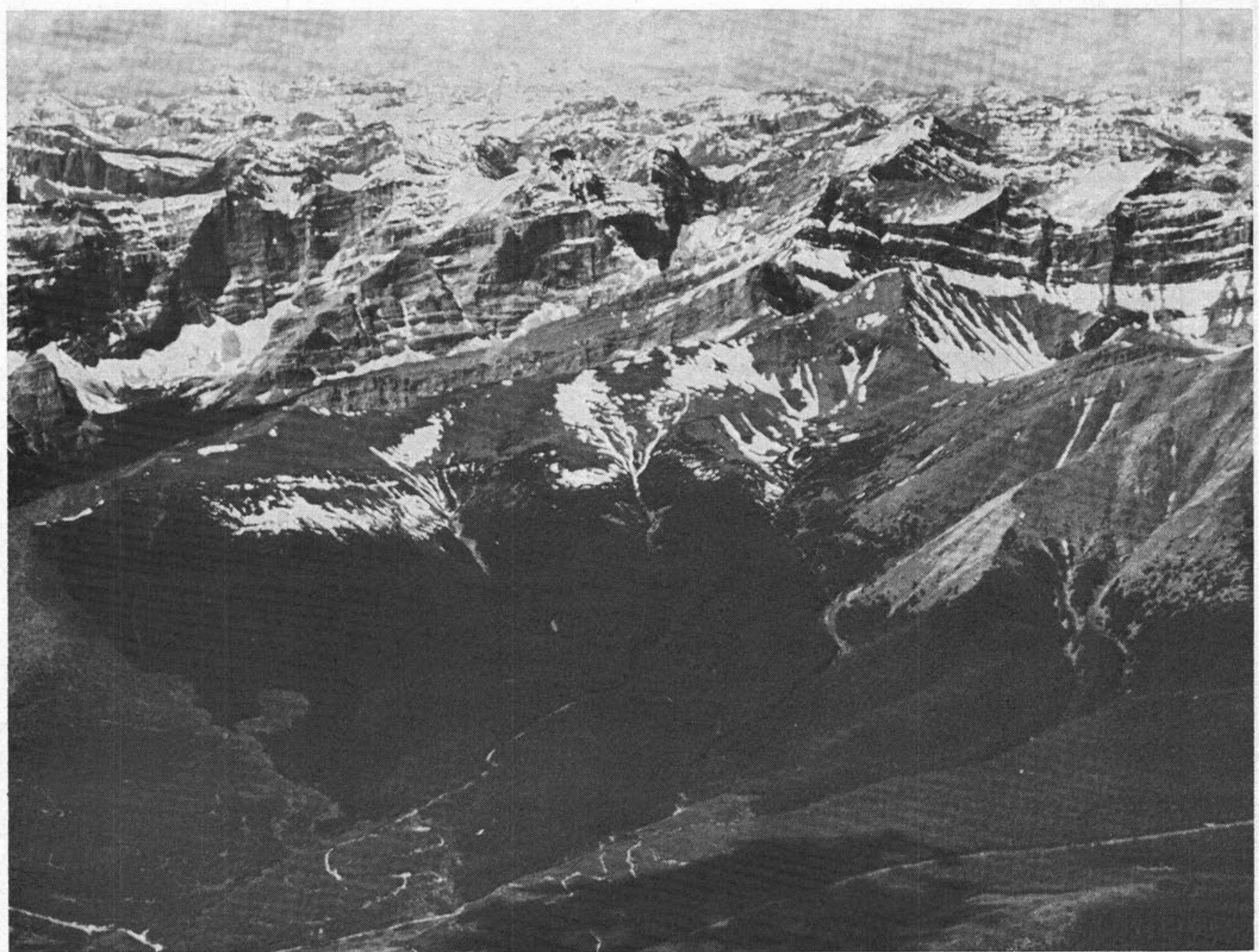

Fig. 2. Marmot Creek experimental watershed. Difficulties of mea suring precipitation, both within and outside the forest, are greatly magnified in terrain such as this. 
nificantly greater than from other land uses. Many assumptions are called for but the method is basically this: Annual wood increment was reduced to half to obtain annual dry wood increment. A "coefficient of transpiration" of 350 (i.e., 350 units of water are required to produce each unit of dry wood) was used to calculate the water required to produce the annual dry wood increment, litter fall, new twigs, and roots. Total water transpired was only four per cent of atmospheric moisture transport for the year, whereas total evapotranspiration from the entire area was 14 per cent. Rakhmanov concluded that forests do not accelerate moisture turnover of the atmosphere or provide moisture for precipitation.

Budyko (1956) attacked the hypothesis of multiple moisture turnover in a more convincing manner. He separated total flux of water vapor in the atmosphere into two components, that transported into a given region and that from local evaporation. Each of these components is considered as it enters the region (windward side) and as it leaves (leeward side). For water vapor originating outside the region,

$$
\begin{aligned}
& \mathrm{V}_{\mathrm{O}_{\mathrm{e}}}=\text { wu } \\
& \mathrm{V}_{\mathrm{O}_{\mathrm{d}}}=\text { wu }-\mathrm{roS} \\
& \text { where } \mathrm{V}_{\mathrm{O}_{\mathrm{e}}}=\text { water vapor entering the region } \\
& \mathrm{V}_{\mathrm{O}_{\mathrm{d}}}=\text { water vapor originating outside the region that } \\
& \mathrm{w}=\text { leaves the region } \\
& \mathrm{u}=\text { atmospheric moisture content, windward side } \\
& \mathrm{ro}=\text { precipitation in the region formed from water } \\
& \mathrm{S}=\text { vapor originating outside the region } \\
& \mathrm{V}_{\mathrm{I}_{\mathrm{d}}}=\left(\mathrm{E}-\mathrm{r}_{\mathrm{I}}\right) \mathrm{S} \\
& \mathrm{E}=\text { leaves the region } \\
& \mathrm{I}_{\mathrm{I}}=\text { precipitation in the region formed from water } \\
& \text { vapor originating within the region }
\end{aligned}
$$

On the average, the atmosphere over the region contains water vapor originating outside the region equal to $1 / 2\left[(w u)+\left(w u-r_{0} S\right)\right]$, and originating inside the region equal to $1 / 2\left[(0)+\left(E-r_{I}\right) S\right]$. Assuming that water vapor entering the region and that originating within the region are completely mixed in the atmosphere by turbulent exchange, the ratio of precipitation formed by locally- and externally-originating water vapor is equal to the ratio of locally- and externally-originating water vapor in the atmosphere over the region.

That is,

$$
\frac{r_{1}}{r_{0}}=\frac{1 / 2\left(E-r_{1}\right) S}{w u+1 / 2 \operatorname{roS}}
$$

With these relationships, components of the hydrologic cycle were calculated for European Russia. Precipitation from locally-originating water vapor constituted 10.9 per cent of total annual precipitation, with monthly values ranging from 4.1 (October) to 18.4 per cent (May).

A modification of Budyko's theory was used to calculate the water balance for Canada and the United States for 1949. Local evaporation accounted for 27 per cent of annual precipitation, and 11, 26,40 , and 25 per cent of winter, spring, summer, and fall precipitation, respectively (Sellers 1965). It may be incorrect to assume that the ratio of precipitation formed by locally- and externally-originating water vapor is equal to the ratio of locally- and externally-originating water vapor in the atmosphere. Initially, at least, water vapor of local origin is concentrated near the surface and may form more than a proportional share of precipitation, in which case Seller's and Budyko's figures are underestimates.

Granting that on a continental basis about 10 to 25 per cent of precipitation originates from local evaporation, what does this tell us about the effect of forests on precipitation? Budyko showed that the smaller the area considered, the smaller is the proportion of precipitation originating from local evaporation. Let us assume then that 10 per cent of precipitation over an extensive forest originates from local evaporation. On the average, evapotranspiration from grassland and cultivated crops is about 90 and 60 per cent as great, respectively, as from forest (Baumgartner 1967). That is, if 10 per cent of precipitation over a forested area originates from local evaporation, the figure is nine per cent for grassland and six per cent for cultivated land. That is, precipitation may be from one to four per cent greater on forest land than on grassland and cultivated land.

\section{Qualifications}

\section{Moistening Effect of the Forest}

Even though arguments using the meteorological approach generally disclaim the effect of forests on precipitation, many contain a qualifying statement. Holzman (1937) admitted that in conditions approaching stagnation of atmospheric circulation, very light rain may result from transpiration from local vegetation. Molchanov (1960) stated that for short periods local evaporation may increase rainfall, especially when atmospheric circulation prevents transport of large amounts of moisture.

\section{Orographic Effect}

For precipitation to occur clouds must be formed by cooling and condensation of water vapor in the air. This occurs when air is forced upward by the movement of large-scale air masses, convection, or the configuration of the land surface. It is the last that is of interest here.

The effect of mountains and valleys on precipitation is often very striking. For example, annual precipitation in the Coast Mountains of British Columbia is 150 inches or more, and as low as 12 inches 50 miles to the east. The height of the physical obstruction is important, especially when considering less extreme topographic variations. Penman (1963) suggests that "a range of hills with trees on top could be a slightly more efficient wedge than the same hill without trees" (p. 7). Brooks (1928) showed that the increase in effective height of the land surface by 33-foot trees increased precipitation by about one per cent. Molga (1962), estimated the annual increase to be as high as six per cent in some locations. 
Brooks (1928) estimated a two per cent increase in precipitation due to canopy roughness decreasing wind velocity and causing ascent. Bergeron (1961), Hosler et al. (1962), and Timmerman (1963) included the roughness factor as relevant to precipitation increase. Federov and Burov (1967) concluded that forests increase rainfall by 10 to 15 per cent due to the orographic effect of both the forest edge and canopy roughness.

\section{Presence of Condensation Nuclei}

It had long been assumed that ocean salt was the principle source of nuclei for water-vapor condensation in the atmosphere, but Simpson (1941) suggested that other nuclei may be important. He concluded that "nuclei for normal cloud formation cannot be derived from sea-spray; for there are nothing like sufficient drops of spray to produce the large number of nuclei required to supply an average rainfall" (p. 168). Recently it has been suggested that sublimated terpenes (volatile plant products) act as nuclei and hence affect precipitation (Hickman 1966). Went et al. (1967) showed that even where no man-made air pollutants exist, large numbers of condensation nuclei are formed every day, through a photo-chemical process by which terpenes are activated to agglomerate into particles.

The world's production of plant volatiles released to the atmosphere every year is estimated at $4.38 \mathrm{x}$ $10^{8}$ tons (Rasmussen and Went 1965). It may be, then, that because they serve as condensation nuclei and are present in quantity in the atmosphere, sublimated terpenes have a significant influence on precipitation. However, the production of terpenes is particularly characteristic not only of some trees, but of other plants as well (Bonner 1950). If sublimated terpenes do influence the amount of precipi-

\section{References}

BAUMGARTNER, A. 1967. Energetic bases for differential vaporization from forest and agricultural lands. Proc. Int. Symp. on Forest Hydrol., Penn. State Univ. Pergammon Press. p. 381-389.

BENTON, G. S., BLACKBURN, R. T. and SNEAD, V. O. 1950. The role of the atmosphere in the hydrologic cycle. Trans. Amer. Geophys. Union 31: 61-73.

BERGERON, T. 1961. Preliminary results of Project Pluvius. Int. Ass. of Sci. Hydrol Publ. No. 53:226-237.

BERNARD, E. A. 1945. Le climat écologique de la cuvette Centrale Congolaise. Inst. Nat. pour l'étude Agron. du Congo Belge. Brussels. 240 p.

BONNER, J. 1950. Plant biochemistry. Academic Press Inc., New York. 537 p.

BROOKS, C. E. P. 1928. Influence of forests on rainfall. Quart. J. Roy. Meteorol. Soc. 54 (225): 1-13.

BRUCE, J.P. and CLARK, R. H. 1966. Introduction to hydrometeorology. Pergamon Press Ltd., Toronto. $319 \mathrm{p}$.

BUDYKO, M. I. 1956. The heat balance of the earth's surface. Translation by U.S. Dept. of Commerce, Weather Bureau, Washington, D.C. 1958. 259 p.

DOKUCHAEV, V. V. 1892. Our steppes, in former times and at present. SPb (in Russ.). (Original not seen; quoted by Molchanov 1960).

FEDOROV, S. F. and BUROV, A. S. 1967. Influence of the forest on precipitation. Amer. Geophys. Union, Soviet Hydrology: Selected Papers, No. 3: 217-227.

GEIGER, R. 1965. The climate near the ground. Translation of 4 th German edition, 1961. Harvard Univ. Press, Cambridge, Mass. $611 \mathrm{p}$.

HARRINGTON, M. W. 1902. Review of forest meteorology tation the question remains as to whether trees have a significantly greater effect than other plants. Geographical extent of each plant, its density, and its terpene production are relevant factors.

The main factor limiting precipitation in temperate zones, however, is not the absence of condensation nuclei but of ice-forming or freezing nuclei. Cloud seeding with silver iodide to increase precipitation is based on the assumption that there is an insufficient number of particles in the atmosphere serving as freezing nuclei. There is evidence that this may be so, particularly when cloud tops are at a temperature of about $-10^{\circ} \mathrm{C}$ (Bruce and Clark 1966).

\section{Conclusion}

Early arguments supporting the influence of forests on precipitation were legitimately criticized by those suggesting a meteorologic approach in that much of the evidence was circumstantial and based only on casual observation. However, evidence presented by meteorologists is neither conclusive nor completely satisfying. Some proponents of the physical approach admit a small forest influence either because of the orographic influence of the effective increase in elevation (Brooks 1928, Penman 1963 ), a similar effect caused by canopy roughness (Bergeron 1961, Hosler et al. 1962, Timmerman 1963 ), or additional moisture from transpiration in special cases, e.g., atmospheric stagnation (Holzman 1937, Molchanov 1960).

However, on the basis of available evidence and theory we must conclude that forests have very little effect on the total amount of precipitation falling on extensive regions or even on local areas. The maximum effect that may reasonably be attributed to the influence of the forest is a five per cent increase in precipitation.

observations: A study preliminary to the discussion of the relation of forest to climate. U.S. For. Serv. Bull. 7: 23-122. HICKMAN, K. 1966. Oases for the future. Science 154: 612 617.

HOLZMAN, B. 1937. Sources of moisture for precipitation in United States. U.S. Dept. Agr. Tech. Bull. 589. 41 p.

HORTON, R. E. 1943. Hydrologic interrelation between lands and oceans. Trans. Amer. Geophys. Union 24: 753-764.

HOSLER, C. L., DAVIS L. G. and BOOKES, D. R. 1962. The role of orographic barriers of less than 3000 feet in the generation and propagation of showers. Penn. State Univ. Dept. of Meteorol. $137 \mathrm{p}$

HUGHES, J. F. 1949. The influence of forests on climate and water supply. For. Abstr. 11(2): 145-153.

KASATKIN I. I. 1927. Enhancing the internal moisture circulation. Materialy rabot opytno-orositel'noi chasti NKZ, No. 18 (in Russ.) (Original not seen; quoted in Molchanov 1960).

KASHIN, K. I. and POGOSYAN, Kh. P. 1950. Moisture circulation in the atmosphere. Meteorologiya i gidrologiya, No. 2 (in DRuss.) (Original not seen; quoted $n$ Molchanov 1960).

KITTREDGE, J. 1948. Forest influences. McGraw Hill, New York. $394 \mathrm{p}$.

LAW, F. 1958. Measurement of rainfall, interception and evaporation loss in a plantation of Sitka spruce trees. Int. Ass. Sci. Hydrol. 11th Gen. Assembly, Toronto. 2: 397-411.

MARSH, G. P. 1965. Man and nature. The Belknap Press of Harvard Univ. Press. Cambridge, Mass. 472 p. (originally published in 1864).

MOLCHANOV, A. A. 1960. The hydrological role of forests. 
Acad. of Sci. of the U.S.S.R. Inst. of For. Translated from Russian by Prof. A. Gourevitch, Israel Program of Sci. Transl. Ltd. Cat. No. 870, Jerusalem, 1963. 407 p.

MOLGA, M. 1962. Agricultural meteorology. Part II, Outline of agrometeorological problems. Translated from Polish for the Nat. Sci. Found. and the U.S. Dept. of Agr. 351 p.

PENMAN, H. L. 1963. Vegetation and hydrology. Commonwealth Agr. Bur. Tec. Commun. No. 53, $124 \mathrm{p}$.

PINCHOT, G. 1909. Discusson on CHITTENDEN, H. M. 1909. Forests and reservoirs in their relation to streamflow, with particular reference to navigable rivers. Trans. Amer. Soc. Civ Eng. 62: 245-546.

RAKHMANOV, V. V. 1962. Role of forests in water conservation. Transiated from Russian by Prof. A. GOUREVITCH and L. M. HUGHES, 1966, Israel Program for Sci. Transl. Ltd. $192 \mathrm{p}$.

RASMUSSEN, R. A. and WENT, F. W. 1965. Volatile organic material of plant origin in the atmosphere. Proc. Nat. Acad. of Sci. 53: 215-220.

SELLERS, W. D. 1965. Physical climatology. Univ. of Chicago Press, Chicago. $272 \mathrm{p}$

SIMPSON, G. C. 1941. Sea salt and condensation nuclei. Quart. J. Roy. Meteorol. Soc. 67: 163-169.
STORR, D. 1967. Precipitation variations in a small forested watershed. Proc. 35th Annual Western Snow Conference. p. $11-17$.

SUTCLIFFE, R. C. 1956. Water balance and the general circulation of the atmosphere. Quart. J. Roy. Meteorol. Soc. 82: 385-395.

TIMMERMAN, H. 1963. The influence of topography and oro graphy on the precipitation patterns in the Netherlands. Roy. Dutch Meteorol. Inst. No. 80. 49 p.

WARREN, H. N. 1945. Bradfield scheme for watering the inland: Meteorological aspects. Australian Commonwealth Meteorol. Bur. Bull. 34. 82 p.

WENT, F. W., SLEMMONS, D. B. and MOZINGO, H. N. 1967. The organic nature of atmospheric condensation nuclei. Proc. Nat. Acad. of Sci. 58 (1): 69-74.

ZON, R. 1927. Forests and water in light of scientific investigation. U.S. Nat. Waterways Comm. Final Rep.. 62nd Cong., 2nd Sess. Senate Doc. 469. Append. 5: 205-302.

ZON, R. 1935. Shelterbelts, futile dream or workable plan. Science 81 (2104): 391-394.

ZON, R. 1945. Forests in relation to soil and water. Proc. Amer. Phil. Soc. 89: 399-402.

\title{
Methods for Ensuring
} Additivity of Biomass

\section{Components by}

\section{Regression Analysis}

\author{
By A. KOZAK
}

Faculty of Forestry

The University of British Columbia

Vancouver 8, B.C.

ODC 53

\begin{abstract}
In many forestry problems additive regression equations are expected because of the nature of the data. This paper discusses the reasons why one does or does not have these additive equations. Mathematical proofs of the theory are given, with a numerical example.
\end{abstract}

Techniques de regression qui tiennent compte de l'additivité des facteurs dans l'étude de la biomasse

\section{Résumé}

Plusieurs problèmes forestiers peuvent être analysés au moyen d'équations de régression additives. L'auteur discute des conditions qui permettent d'obtenir de telles équations, fait la démonstration mathématique des principes en cause et illustre par un exemple numérique.

\section{Introduction}

A common complaint by scientists working on biomass studies is that predicted values calculated from the "component equations" do not add up to the predicted value calculated from the "total equation". An example will make this statement clear. If regression equations of some form are fitted for a certain tree species between diameter at breast hight $(X)$ as the independent variable, and the weight of bole $\left(Y_{1}\right)$, the weight of bark on the bole
$\left(Y_{2}\right)$, the weight of crown (branches and foliage) $\left(Y_{3}\right)$ and total weight $\left(Y_{4}=Y_{1}+Y_{2}+Y_{3}\right)$, as four different dependent variables, one would call the first three equations component equations and the last one the total equation. Also, one would expect that the sum of the predicted values from the component equations would be equal to the predicted value from the total equation (Young, Strand and Altenberger, 1964, and Kurucz, 1969).

Similar problem exists in several fields in forestry and forest research. For example in logging, when a time study is conducted, equations can be set up for haul-out time $\left(Y_{1}\right)$, hook-up time $\left(Y_{2}\right)$, haul-in time $\left(Y_{3}\right)$, loading time $\left(Y_{4}\right)$, delay time $\left(Y_{5}\right)$, and total time $\left(Y_{6}=Y_{1}+Y_{2}+Y_{3}+Y_{4}+Y_{5}\right)$ as dependent variables, on volume in the load $\left(X_{\mathrm{I}}\right)$, horse power of the machine $\left(X_{2}\right)$ and distance $\left(X_{3}\right)$ as independent varaibles. Sawmill production studies where the volume of several grades and the total volume produced per day are studied over one or more independent variables, are another example of this problem (Schumacher and Younger, 1943).

This paper discusses the conditions under which additive equations can be fitted, and gives formulae for calculation of the standard error of estimate $\left(\mathrm{SE}_{\mathrm{E}}\right)$ and coefficient of determination $\left(\mathrm{R}^{2}\right)$ for the total equation from the statistics of component equations, without fitting the total equation. 